\title{
Repolarizáló káliumáramok tulajdonságainak vizsgálata sinusritmusú és pitvarfibrilláló kutyákból izolált pitvari szívizomsejteken
}

\author{
Kohajda Zsófia', Kristóf Attila1, Horváth András², Juhász Viktor², Sághy László3, \\ Virág László², Baczkó István², Fazekas Tamás", Varró András,2, Jost Norbert'1,2
}

\author{
${ }^{1}$ MTA-SZTE, Keringésfarmakológiai Kutatócsoport, Szeged \\ ${ }^{2}$ SZTE, Általános Orvostudományi Kar, Farmakológiai és Farmakoterápiai Intézet, Szeged \\ ${ }^{3}$ SZTE, Általános Orvostudományi Kar, II. sz. Belgyógyászati Klinika és Kardiológiai Központ, Szeged \\ ${ }^{4}$ SZTE, Általános Orvostudományi Kar, I.sz. Belgyógyászati Klinika, Szeged
}

Levelezési cím: Dr. Jost Norbert, tudományos főmunkatárs, SZTE ÁOK, Farmakológiai és Farmakoterápiai Intézet 6701 Szeged, Dóm tér 12, Pf.: 427. E-mail: jost.norbert@med.u-szeged.hu

\begin{abstract}
Célkitűzés: A vizsgálat célja a pitvari repolarizációt meghatározó és a pitvarfibrillációt (PF) kísérő elektromos átépülésben szerepet játszó kálium-ionáramok $\left(I_{t o}-\right.$ tranziens kifelé haladó kálium; $I_{K 1}$ - befelé egyenirányító kálium és $I_{K, A c h}$ - acetilkolin szenzitív káliumáram) vizsgálata volt sinusritmusú (SR) és krónikus gyors (400/perc) pitvari elektromos ingerléssel kiváltott PF-ben lévő kutyákból izolált pitvari szívizomsejtekben.

Módszerek: A kutyákon a pitvari remodellinget és PF-t krónikus (4-6 hét) gyors (400/perc) pitvari elektrostimulációval váltottuk ki. Az ionáramokat a patch clamp technika egész sejtes konfigurációjában mértük jobb pitvari szívizomsejteken $37^{\circ} \mathrm{C}$-on. Eredmények: A PF-ben szenvedő kutyákból izolált cardiomyocytákban az $I_{\text {to }}$ kis mértékben gyengült (downregulálódott). $A z I_{K 1}$ hasonló mértékü volt a PF és az SR sejtekben. A pitvarspecifikus $I_{K, A C h}$ ionáram aktiválásához carbacholt (CCh) alkalmaztunk. Az „SR-sejtekben” aktivált outward áramot $10 \mathrm{nM}$ tertiapin, az $\mathrm{I}_{\mathrm{K}, \mathrm{ACh}}$ szelektív gátlószere, 61\%-ban csökkentette. A „PF-sejtekben”, minden elözetes aktiváció nélkül, jelentős, konstitutívan aktív $I_{K, A C h}$ áramot mértünk, amelyet a tertiapin $59 \%$ ban gátolt. Ha a „PF-sejteket” carbachollal kezeltük, bennük a konstitutív $I_{\mathrm{KACh}}$ ionáramon kívül szignifikáns ligand-függő és szintén tertiapin szenzitív $I_{K, A C h}$ ionáram jelent meg.

Következtetések: A konstitutív $I_{K, A C n}$ megjelenése is igazolja, hogy az általunk alkalmazott PF-kutyamodellben a pitvari elektromos remodelling egyértelmúen kialakult. A ligandfüggö és konstitutíven aktív $I_{K, A C h}$ együttesen fontos szerepet játszik kutyában a PF-t kísérő elektromos átépülés kialakitásában, így ígéretes antiaritmiás gyógyszertámadási célpont lehet.
\end{abstract}

Kulcsszavak: pitvarfibrilláció, pitvari remodelling, szívelektrofiziológia, acetilkolin szenzítív káliumáram

Properties of several repolarizing potassium currents in atrial cadiomyocytes isolated from dogs in sinus rhythm and atrial fibrillation

Aims: The aim of the present study was to investigate the properties of three repolarizing potassium currents which contribute to atrial fibrillation (AF) - induced electrical remodelling, i.e. the transient outward $\left(\mathrm{I}_{\mathrm{t}_{0}}\right)$, inward rectifier $\left(\mathrm{I}_{\mathrm{K}_{1}}\right)$ and acetylcholine-sensitive $\left(I_{K, A C h}\right)$ potassium currents in isolated atrial myocytes obtained from dogs either with sinus rhythm (SR) or following chronic atrial tachypacing (400/min) AF-dogs.

Methods: Atrial remodelling and AF were induced by chronic (4-6 weeks of) right atrial tachypacing $(400 / \mathrm{min})$ in dogs. Transmembrane ionic currents were measured by applying the whole-cell patch clamp technique at $37^{\circ} \mathrm{C}$.

Results: The $\mathrm{I}_{\mathrm{t}}$ current was slightly downregulated in AF cells when compared with that recorded in SR cells. $\mathrm{I}_{\mathrm{K} 1}$ current was not statistically significant different in AF and SR cells. $I_{K, A C h}$ was activated by carbachol (CCh; $\left.2 \mu \mathrm{M}\right)$. In SR, CCh activated a large current either in inward or outward directions. The selective $I_{K, A C h}$ inhibitor tertiapin (10 nM) blocked the outward CCh-induced current by $61 \%$. In atrial myocytes isolated from dogs with AF, the presence of a constitutively active $\mathrm{I}_{\mathrm{K}, \mathrm{Ach}}$ was observed, blocked by $59 \%$ with $10 \mathrm{nM}$ tertiapin. However, in 'AF atrial myocytes', CCh activated an additional, significant ligand-dependent and tertiapin-sensitive $\mathrm{I}_{\mathrm{K}, \mathrm{ACh}}$ current.

Conclusions: The presence of the constitutively active $I_{K, A C h}$ in atrial myocytes from AF dogs shows that electrical remodeling truly developed in this model. The $I_{K, A C h}$ current (both ligand-dependent and constitutively active) seems to play a significant role in canine atrial electrical remodeling, and may be a promising atrial selective drug target for suppressing AF.

Keywords: atrial fibrillation, atrial remodeling, cardiac electrophysiology, acetylcholine sensitive potassium current 


\section{Bevezetés}

A pitvarfibrilláció (PF) a leggyakrabban előforduló krónikus/visszatérő ritmuszavar a klinikai gyakorlatban. PF-ben a fiziológiás körülmények (SR) között koordinált pitvari tevékenység helyett teljesen rendezetlen, kaotikus, óriási frekvenciájú (cca. 600-800/min) gyors excitáció jellemzi a pitvarok elektromos müködését, amelyek lényegében véve vonaglanak, érdemi mechanikai tevékenységre (összehúzódásra és ellazulásra) képtelenek. Paroxizmális PF-ben a rendszertelenül és nemritkán (10-40\%) panaszmentes formában jelentkező epizódok/attakok 7 napon belül spontánul megszűnnek, de ha a PF perzisztenssé válik, gyógyszeres terápia vagy elektromos kardioverzió szükséges a SR helyreállítására. Az SR visszaállítását célzó gyógyszeres, elektromos vagy „hibrid (gyógyszer pl. prokainamid vagy ibutilid injektálása után végzett elektrosokk) beavatkozás nem mindig sikeres, és köztudott, hogy annál kisebb a valószínüsége, hogy a betegek SR-ben maradnak, minél hosszabb ideje fennáll(t) a kardioverzió elött a PF. Ha az SR ezen beavatkozások ellenére sem áll helyre vagy kísérlet sem történik helyreállítására (mert pl. a beteg nem egyezik bele az altatás alatt végezhető elektrokardioverzióba), a ritmuszavar állandósul, s ilyenkor a permanens jelzővel illetjük (1). Kísérletes körülmények között rövidebb-hosszabb ideig fentartott gyors pitvari elektrostimulációval PF idézhető elö, amely önfenntartó folyamatként elősegíti (elsősorban nagyobb szívvel bíró állatfajokban) saját fennmaradását. Ezt a jelenséget nevezték el Allessie és munkatársai, ma már klasszikusnak nevezhetően az atrial fibrillation begets atrial fibrillation, azaz „a pitvarfibrilláció pitvarfibrillációt szül” kifejezéssel (2).

A PF kórélettanának megismerése rendkívül sokat fejlődött az elmúlt 20 évben, amelynek során bekerült a köztudatba az atrialis remodelling, azaz a pitvari átépülés fogalma (3). Minden, a PF során előálló pitvari strukturális/szerkezeti, funkcionális/elektrofiziológiai és szignáltranszdukciós/biokémiai elváltozást összefoglalóan pitvari remodellingnek nevezünk. A pitvari remodellingnek számos (részben a kiváltó alapbetegségtől függő) formája/típusa van, mindemellett közös jellemzőjük, hogy elösegítik a PF kiújulását, perzisztenciáját, tartós (long-standing) perpetuációját vagy állandósulását. Lényegében véve, a PF is azokon a kamraizomzatban/szívizomsejtekben is megfigyelhető, mindenkitöl ismert szívritmuszavar-keltő/fenntartó mechanizmusokon alapul, melyeket az 1. ábra szemléltet (4). Pitvarfibrillációt egyaránt okozhat gyors pitvari ektópiás tevékenység/szoliter vagy repetitív extrasystolia vagy

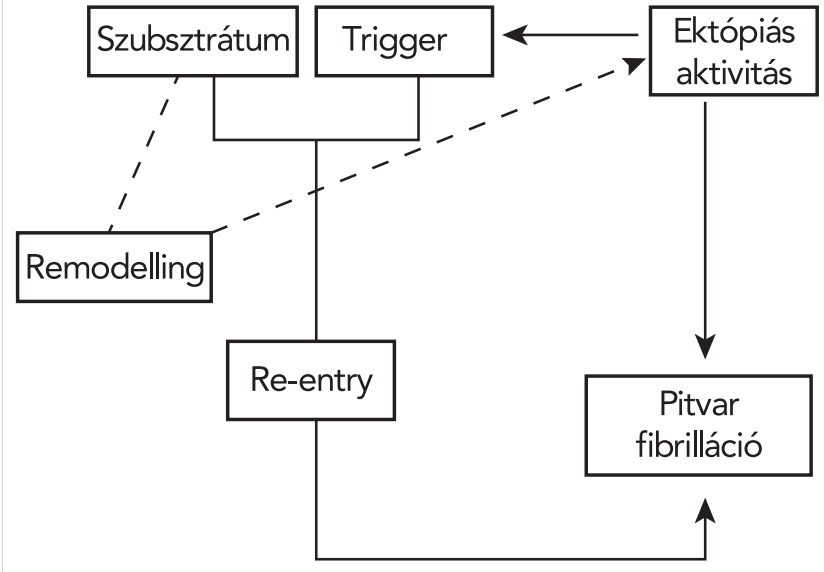

1. ÁBRA. A pitvarfibrilláció kialakulásában és fennmaradásában szerepet játszó főbb tényezők ([4] alapján módosítva; engedéllyel)

ún. re-entry-aktivitás. A PF-et kiváltó, többnyire funkcionális (multiple wavelet)-re-entry iniciálásában és (gyakran a ritmuszavar tartós fönnmaradásában is), a repetitív pitvari ektópiás aktivitásnak/extrasystoliának kulcsfontosságú szerepe van. Már utaltunk arra, hogy minél hosszabb ideje áll fenn a PF, annál kifejezetebb az atrio-endomiokardiális és neurális $(5,6)$ remodelling, $s$ több éve tartó permanens PF-ben az „átépülés” már oly mértékben a progrediál, hogy a pitvarüregek kitágulnak, a pivarizomfal pedig kötőszövet-szaporulat miatt egyre merevebb lesz (stiffnes; fibromiokardiális átalakulás). Chen és munkatársai nemcsak spontán kóros automáciára vagy triggerelt aktivitásra képes cardiomyocytákat találtak kutyák PV-szájadékaiban (a PV-ostiumokban) és a visszerekbe betüremkedő szívizomnyelvekben, hanem olyasféle re-entry-mechanizmust is, aminőt PF-ben szenvedő betegek PV-régióiban is kimutattak (7).

Mindent összevéve, a venoatrialis PF-et elindító extrasystolék (ES-k) patofiziológiai hátterében három aritmogén mechanizmus állhat:

- kóros automácia;

- re-entry;

- triggerelt aktivitás.

Utóbbi lehet a PV-szájadékokból kiinduló spontán ES (fokális PF), amelyet ún. késői (DAD=delayed after depolarization) és/vagy korai $(E A D=$ early after depolarization) utódepolarizáció indukál.

A kialakult/már meglévő pitvari remodelling további komplex (e helyütt nem részletezett) elektrofiziológia és patobiokémiai mechanizmusokon keresztül elősegíti a PF további fennmaradását megalapozó ektópi- 
ás és/vagy re-entry aktivitást. Számos kórfolyamat/ betegség létezik, amely megváltoztatja a pitvarsejtek és a pitvari myocardium elektroanatómai és elektrofiziológiai tulajdonságait, e dolgozatnak ezen kórformák számbavétele nem célja. Általában véve, állatkísérletes és klinikai vizsgálatok alapján a pitvari remodelling két alapformáját különböztetjük meg. Az egyik a pitvari tachycardiától/tachyarrhythmiától indukált típus, amely dominánsan elektromos remodelling (ATR=atrial tachycardia-induced remodeling), amelyet klinikai körülmények között tachyarrhythmiák (PF, pitvarlebegés=AFlu, PSVT-K=paroxizmális supraventricularis tachycardiák) váltanak ki; a másik a pangásos szívelégtelenséghez vagy a kamraizomzat kötőszövet-szaporulattal (fibrosissal) és telődésgátlással járó megbetegedéseihez (mint amilyen pl. a hipertenzió) társuló pitvari strukturális remodelling ( $A S R=$ atrial structural remodeling). A két „remodelling-forma” éles disztinkciója magától értődően nagyon nehéz, hiszen az itt és később fölvázolt (elektro)patofiziológiai folyamatok kart karba öltve járnak.
Az a megfigyelés, hogy már a néhány hétig folyamatosan fennálló PF is képes gyökeresen megváltoztatni a pitvar elektrofiziológiai tulajdonságait és facilitálja a tachyarrhythmia fennmaradását és/vagy állandósulását, az Allessie vezette maastrichti munkacsoport „mérföldkő" elektropatológiai/elektrofizológiai felfedezése volt $(1,2)$. Már céloztunk arra, hogy az ATR-rel indukált PF elsősorban elektromos remodellinget idéz elő (3). Jelenlegi ismereteink birtokában egyelőre nem tudjuk, hogy az ún. long-standing perzisztens és a permanens PF okozta „remodelling-formák” között milyen (mikro) elektrofiziológiai és hisztopatológiai hasonlóságok és különbségek vannak, de az nyilvánvaló, hogy az elektroanatómiai átépülés (sejtszintü és szubcelluláris) jellemzőit nagymértékben befolyásolja a szív-ér rendszeri alapbetegség (8). Ami biztos: az ATR rövidíti az APD-t (2. ábra) (4).

E jelenség hátterében elsősorban az L-típusú $\mathrm{Ca}^{2+}$ áram ( $\left.\mathrm{I}_{\mathrm{CaL}}\right)$ downregulációja áll $(9,10)$, de fontos szerepe van az erősödő háttéráramként működő befelé egyenirányító $\mathrm{K}^{+}$-áramnak $\left(\mathrm{I}_{\mathrm{K} 1}\right)(11)$, valamint a permanens

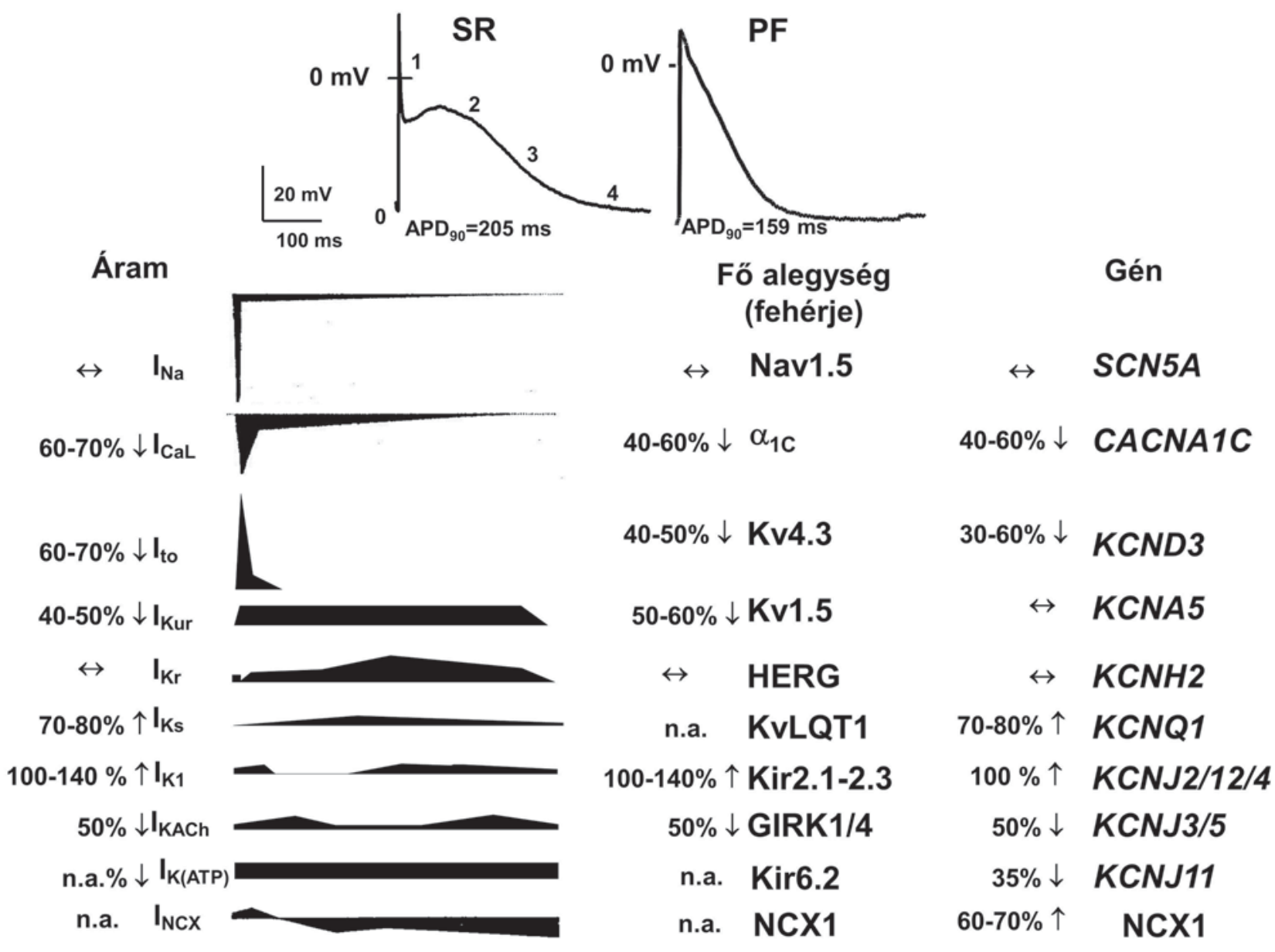

2. ÁBRA. A pitvari akciós potenciált létrehozó kationáramok emberi pitvarsejtekben sinusritmusban (SR) és pitvarfibrillációban (PF); ez az ún. „ioncsatorna-remodelling”. Az áramok intenzitásának százalékban kifejezett változása az ábra bal oldalán, az ioncsatornákat alkotó fő fehérje-alegységeké középen, a kódoló géneké az ábra jobb oldalán látható. A piktogramok az áramerősség akciós potenciál alatti időbeli változását szemléltetik (a méretarány hozzávetőleges figyelembevételével). n.a. = nincs irodalmi adat ([4] alapján módosítva; engedéllyel) 
PF-ben konstitutívan aktív acetilkolin függő káliumáramnak $\left(\mathrm{I}_{\mathrm{K}, \mathrm{ACh}}\right)(11,12)$. Az ATR a Ca ${ }^{2+}$-homeosztázis károsítása révén mindenkor rontja a pitvarok szisztolés/kontrakciós és diasztolés/relaxációs funkcióját (13). A pitvarüregtágulat tovább növeli a re-entry körök keletkezésének valószínűségét (nagyobb a rendelkezésre álló endomiokardiális „szívizomterület”, több szimultán funkcionális re-entry keletkezésének adottak a feltételei) és az újraingerlődés perpetuációját. Mindent összevéve, a patogenezisben a tág(uló) szívpitvarok túltelődése, a vérrögképződést elősegítő pangás (sztázis), a mechanoreceptorokat serkentő falfeszülés (stretch), a kamrák elégtelen (verő- és perctérfogatot csökkentő) telítődése és diasztolés diszfunkciója, a pitvarműködés irregularitására visszavezethető pitvar-kamrai (elektromos és mechanikai) aszinkrónia és még sok más (monografikusan részletezhető) kórtani tényező játszik „interaktív” szerepet (4). Jelen dolgozat célja az „ioncsatornaszintü" remodelling jellemzése.

Az ATR-ben bekövetkező elektromos remodelling során jelentősen megváltozik számos transzmembrán ionáram tulajdonsága, konduktanciája. Ez magában foglalja a sejtmembrán biofizikai, kinetikai tulajdonságaiban bekövetkező eltéréseket, de megváltozhat a kationcsatornák/ionáramok antiaritmiás gyógyszerek iránti érzékenysége, ami akár azt is jelentheti, hogy a PF gyógyszer-rezisztenssé válik vagy éppen egy új, pitvarspecifikus (kizárólag a pitvarizomzatban jelenlévő ioncsatornára ható) ágenssel az eddigieknél hatásosabban megelőzhető és/vagy megszüntethető (3). Számos vizsgálat igazolta, hogy perzisztens PF-ban több $\mathrm{Na}^{+}$- és $\mathrm{K}^{+}$-csatorna gátló antiaritmikum hatása, sinusritmust helyreállító képessége gyengül $(15,16,17)$, ami azzal a régi klinikai megfigyeléssel is összhangban van, hogy minél koraibb a PF diagnózisa, annál nagyobb a farmakológiai kardioverzió sikeraránya (15). Az eddig felvázoltak alapján az ATR potenciális antiaritmiás gyógyszercélpont (pharmacological target) lehet. Ahhoz viszont, hogy új, az ATR megelőzésére és/ vagy megszüntetésére alkalmas antiaritmiás gyógyszereket fejlesszünk ki, szükség van olyan állatkísérletes modellekre, amelyek alkalmasak az új gyógyszerjelöltek ATR-re kifejtett hatásának preklinikai elemzésére. Meglepő módon, a széleskörüen alkalmazott állatkísérletes modelleken (patkány, tengerimalac, nyúl, kutya, kecske) végzett munka során szerzett tapasztalatok és mérések jóvoltából pontosabban ismerjük a humán pitvari ionáramokat (mint a kamraiakat). Több olyan PF-modell létezik, amely alkalmas az ATR-re kifejtett (gyógyszer)hatás(ok) vizsgálatára, jellemzésére. Ezek lényege, hogy a kísérleti állatok (kutya, kecske) szívét viszonylag hosszú ideig nagy frekvenciával mesterségesen ingereljük.

Kísérleteink célja a pitvari repolarizációban és PF-ben előálló elektromos átépülésben (remodelling) szerepet játszó kálium-ionáramok ( $\mathrm{I}_{\text {to }}$-tranziens kifelé haladó kálium, $I_{\mathrm{K} 1}$-befelé egyenirányító kálium és $I_{\mathrm{K}, \mathrm{ACh}}$-acetilkolin szenzitív káliumáram) tanulmányozása volt. Méréseinket SR-ben lévő és gyors pitvari ingerléssel kiváltott PF-ben szenvedő kutyákból izolált pitvari szívizomsejteken végeztük.

\section{Eszkőzök és módszerek}

Kísérleti állatok

A kísérleteket hím, 12-13 kg tömegű Beagle kutyák szívéből izolált pitvari szívizomsejteken végeztük. Az experimentációt a Szegedi Tudományegyetem Munkahelyi Állatkísérletes Bizottsága (MÁB) és a Csongrád Megyei Kormányhivatal Élelmiszerlánc Biztonsági és Állategészségügyi Igazgatósága engedélyezte (I-746/2012 MÁB ill. XIII/1211/2012 számokon).

\section{„Tachypacelt" PF kutyamodell}

Kísérleteinket a korábbiakban leírt módszerek (14) szerint végeztük. Xylazin (indukció: $1 \mathrm{mg} / \mathrm{ttkg}$ iv., fenntartó adag 0,2 mg/ttkg iv. 20 percenként) és ketamin (indukció: $10 \mathrm{mg} / \mathrm{ttkg}$ iv., fenntartó dózis $2 \mathrm{mg} / \mathrm{ttkg}$, iv. 20 percenként) anesztézia bevezetése után az állatok kétoldali szubkután zsebbe helyezett pacemaker-t (Logos, Karios; Biotronik Hungaria Kft.) helyeztünk, amelyeket a jobb kamrába és jobb pitvarba felvezetett, majd rögzített pacemaker-elektródákhoz csatlakoztattunk. Az állatokon az atrioventricularis (AV) csomó rádióhullámú transzkatéteres ablációjával harmadfokú AV-blokkot hoztunk létre, hogy az elektromosan ingerelt pitvarok gyors (400/perc) elektromos müködésének/impulzusainak kamrákra való „lefutását” megakadályozzuk. Az állatokon a kamrai pacemaker által vezérelt szívfrekvenciát az adott állaton mütét előtt mért normális/nyugalmi szívfrekvenciára állítottuk be ( $\pm 80-90 / p e r c)$. A mütétet követő hetedik napon a jobb pitvari pacemakert, előzetes ERP-mérés uán, bekapcsoltuk, majd 400/perc frekvenciával gyors jobb pitvari ingerlést kezdtünk az elektromos remodelling létrehozása céljából, amelyet korábbi vizsgálataink szerint a jobb pitvari ERP 80 ms-nál rövidebb időtartama jelzett. A tartós és gyors pitvari elektrostimuláció okozta elektromos remodelling dacára az SR-kutyában nemritkán helyreáll; ilyenkor 800/perc frekvenciával 10 másodperces pitvari „burst” ingerléssel reindukáltuk a PF-et. A pacemaker-ek működésének szabályozása ICS 3000 Programmer (Biotronik Hungaria Kft.) segítségével történt.

\section{J obb pitvari szívizomsejtek izolálása}

A kutya jobb pitvari szívizomsejtjeinek izolálását enzimatikus úton végeztük. A kísérleti állatokat előzetes szedálás (xylazin, $1 \mathrm{mg} / \mathrm{ttkg}$ iv. és ketamin, $10 \mathrm{mg} / \mathrm{ttkg}$ iv.) után pentobarbitállal (Sigma-Aldrich, $30 \mathrm{mg} / \mathrm{ttkg} \mathrm{iv}$ ) (el)altattuk, majd a szívet jobb oldali lateralis thoracotomia során gyorsan eltávolítottuk. Az állatok a szívkivétel előtt 400 NE/kg Na-heparint kaptak. A szíveket $4{ }^{\circ} \mathrm{C}$ hőmérsékletü fiziológiás tápoldatban átöblítettük. $A$ jobb 
pitvar perfúzióját a jobb arteria coronariába vezetett branülön keresztül végeztük $60 \mathrm{~cm}$ magas Langendorff perfúziós berendezésen. A jobb pitvart a következő oldatokkal perfundáltuk: $1 \mathrm{mM} \mathrm{Ca}^{2+}$ és $1 \mathrm{ml}$ heparint tartalmazó izolációs oldattal (5 percig), $\mathrm{Ca}^{2+}$-mentes izolációs oldattal (10 percig), $\mathrm{Ca}^{2+}$-mentes izolációs oldattal (40 percig), amelyhez kollagenázt (Clostridium histolyticum type I, 0,54 mg/ml Sigma Chemical, St. Louis, $\mathrm{MO}$, USA), 0,1\% BSA-t (bovine serum albumin fraction V; Sigma Chemical), a 15. percben proteázt (type XIV, $0,05 \mathrm{mg} / \mathrm{ml}$; Sigma Chemical) adtunk. Ezt követően a jobb pitvart levettük a berendezésről, apró darabokra vágtuk, és $1 \mathrm{mM} \mathrm{Ca}{ }^{2+}, 1 \% \mathrm{BSA}$ (bovine serum albumin fraction V; Sigma Chemical) tartalmú oldatba helyeztük (15 percig pihentettük $37^{\circ} \mathrm{C}$-on). A szövetdarabokat szuszpendáltuk és megkaptuk az egyedüli pitvari szívizomsejteket. Az egész izolációs eljárás alatt az oldatokat $100 \% \mathrm{O}_{2}$-vel buborékoltattuk, g a hőmérsékletet $37{ }^{\circ} \mathrm{C}$-on tartottuk. A sejteket 10 percig ülepítettük, majd ezt követően eltávolítottuk a felülúszót és friss oldatot adtunk hozzá. Ezt a folyamatot 3 alkalommal megismételtük. A sejteket mérésig szobahőmérsékleten állni hagytuk.

Az izoláció során alkalmazott oldat (mM/l): $\mathrm{NaCl}$ : 135 $\mathrm{KCl}: 4,7, \mathrm{KH}_{2} \mathrm{PO}_{4}$ : 1,2, $\mathrm{MgSO}_{4}$ : 1,2, HEPES: 10, glükóz: 10, taurin 20; $\mathrm{NaHCO}_{3} 4,4$; Na-piruvát; 5, pH 7,2 (Na$\mathrm{OH}$-val beállítva).

\section{Mérési eszközök, technikák}

A sejteket Olympus IX51 típusú inverz mikroszkóp asztalához rögzített szervfürdőbe helyeztük, amit normális hőmérsékletü, $36-37{ }^{\circ} \mathrm{C}$-os Tyrode oldattal (NaCl: $144 \mathrm{mM} / \mathrm{l}, \mathrm{KCl}: 4,0 \mathrm{mM} / \mathrm{l}, \mathrm{NaH}_{2} \mathrm{PO}_{4}$ : 0,4 mM/l, $\mathrm{MgSO}_{4}$ : 0,53 mM/l, HEPES: $5 \mathrm{mM} / \mathrm{l}$, glükóz: 5,5 mM/l, $\mathrm{CaCl}_{2}: 1,8 \mathrm{mM} / \mathrm{l} ; \mathrm{pH} 7,4 \mathrm{NaOH}$-val beállítva) áramoltattunk át (3. ábra). A 2,0-2,5 M ellenállású patch clamp mikropipettát a következő oldattal töltöttük fel (mM/l): K-aszpartát: $100 \mathrm{mM} / \mathrm{l}, \mathrm{KCl}: 45 \mathrm{mM} / \mathrm{l}, \mathrm{MgATP}$ : $3 \mathrm{mM} / \mathrm{l}, \mathrm{MgCl}_{2}: 1 \mathrm{mM} / \mathrm{l}$, EGTA: $10 \mathrm{mM} / \mathrm{l}$, HEPES: 5 $\mathrm{mM} / \mathrm{l}$ ( $\mathrm{pH}: 7,2, \mathrm{KOH}$-al beállítva). A membránáramokat Axopatch 200B típusú patch clamp erősítővel (Molecular Devices; Union-City, USA), a patch clamp

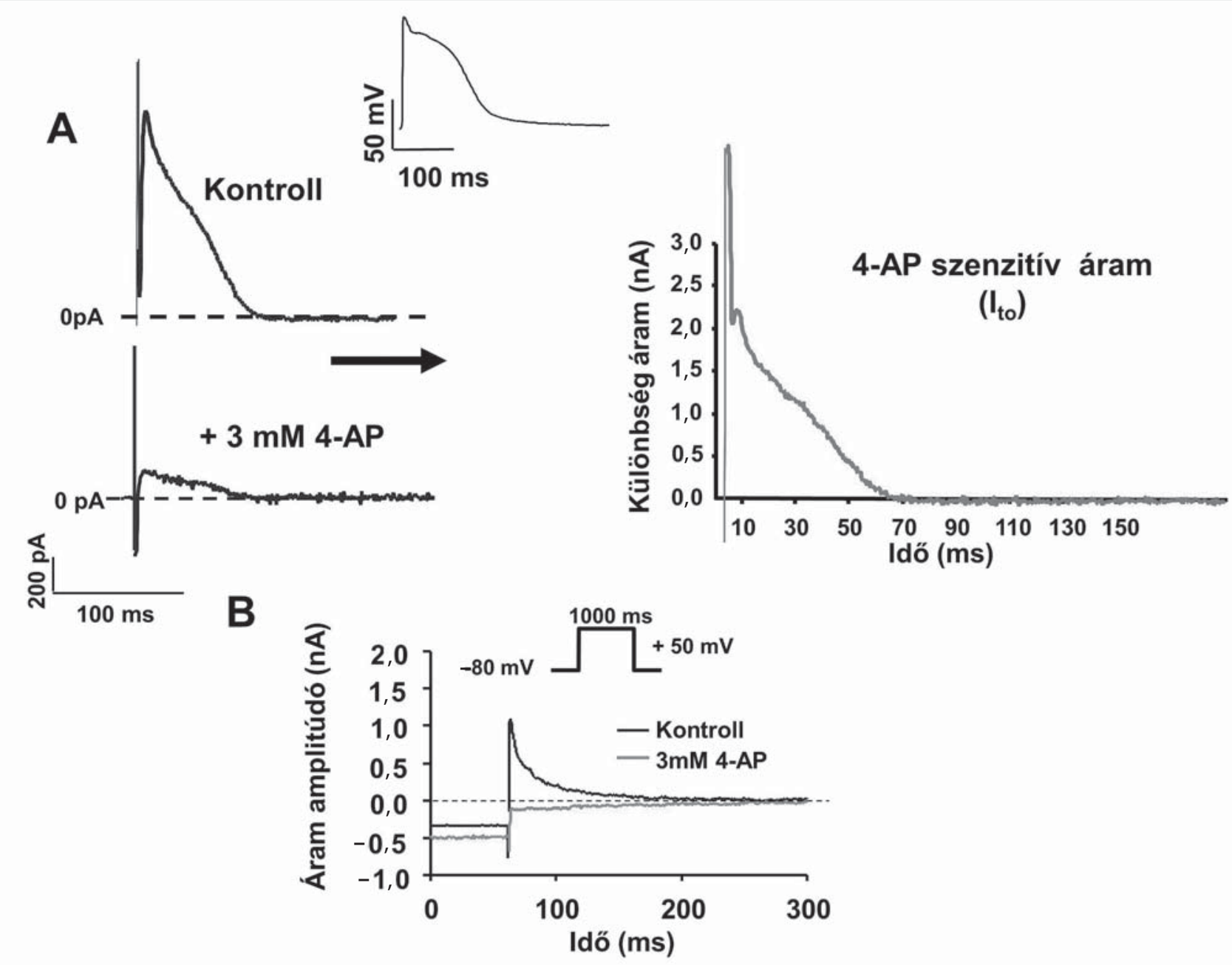

3. ÁBRA. 3 mM 4-aminopyridin (4-AP) érzékeny tranziens kifelé haladó káliumáram (Ito azonosítása akciós potenciálszerű (A-mező) és négyszögletű (B-mező) feszültség-impulzus alkalmazásával kutyából izolált jobb pitvari szívizomsejtekben. Az alkalmazott feszültség-protokollokat az ábrán piktogrammal jeleztük 

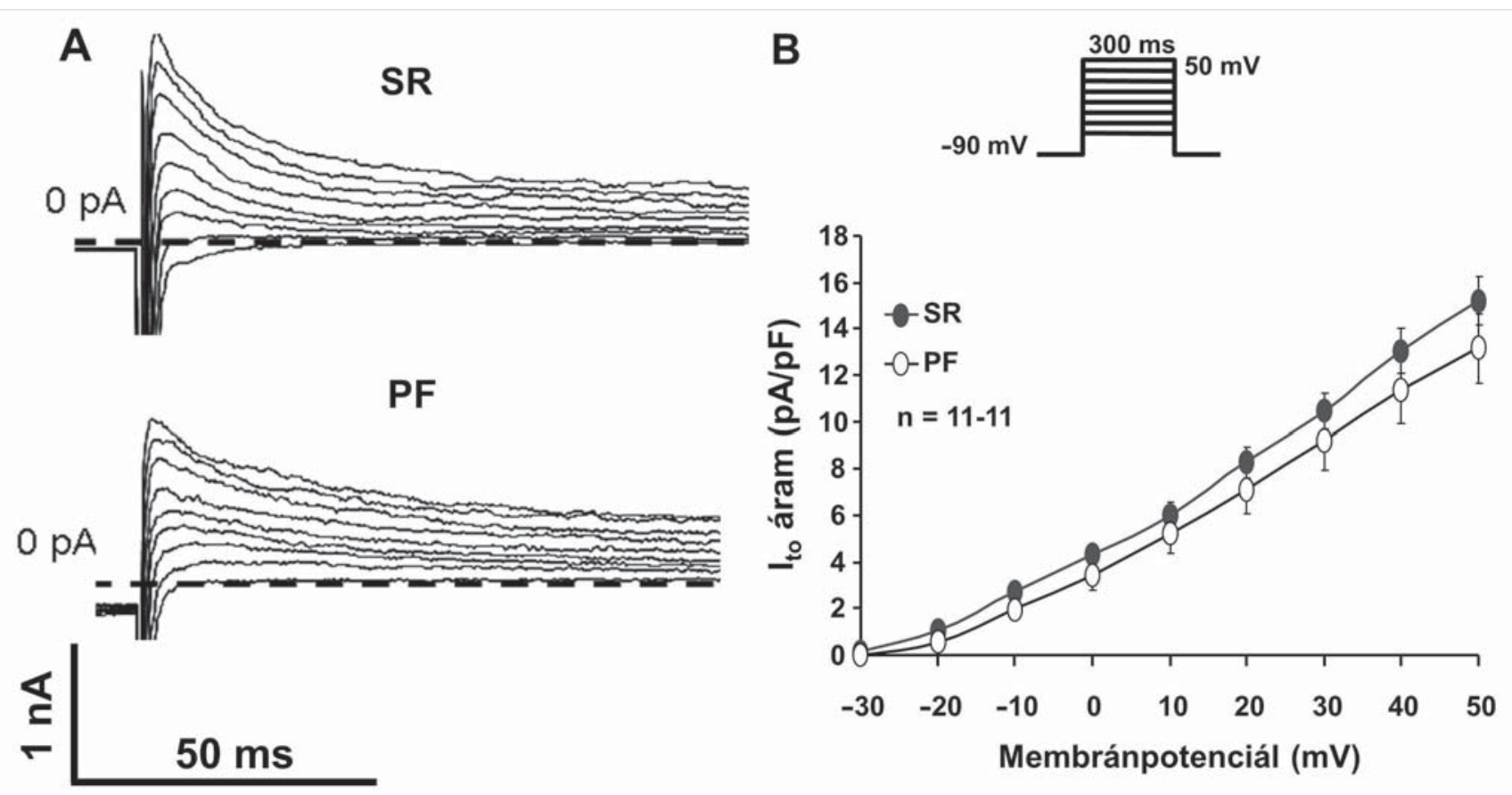

4. ÁBRA. A-mező. Eredeti I áram-regisztrátumok sinusritmusban (SR) lévő és pitvarfibrilláló (PF) kutyákból izolált pitvari szívizomsejteken. Az áramot 0,33 Hz pulzusfrekvencia mellett négyszögjel formájú, 300 ms időtartamú, $-20 \mathrm{mV}$-tól $50 \mathrm{mV}$-ig terjedő depolarizáló feszültségimpulzusokkal aktiváltuk. B-mező. I to áram-feszültség (I-V) karakterisztika SR-os és PF-es kutyákból izolált pitvarsejteken ( $n=11-11, p=n s)$

technika egészsejtes (whole-cell) konfigurációjában mértük. A sejtek kapacitását $10 \mathrm{mV}$-os hiperpolarizáló pulzus segítségével, $-90 \mathrm{mV}$ holding potenciálról (az a potenciálérték, amelyen a sejtet két egymást követő feszültséglépcső után tartjuk) határoztuk meg. A mérések folyamán a 4-8 M $\mathrm{M}$-os ellenállást $50-80 \%$ ig kompenzáltuk. Azoknak a kísérleteknek az eredményeit, ahol a soros ellenállás a mérés folyamán jelentősen megemelkedett, kihagytuk az értékelésből. A membránáramokat $333 \mathrm{~Hz}$-es szoftvervezérelt (Axon pClamp 10.3) analóg-digitális kártya (Digidata 1440, Molecular Devices) segítségével digitálisan mértük, és rögzítettük. Az áramméréseket ugyanazon szoftver segítségével (Axon pClamp 10.3) értékeltük. A kísérleteket fiziológiás hőmérsékleten (37 $\left.{ }^{\circ} \mathrm{C}\right)$ végeztük.

A mérések során a különböző áramokat szelektív gátlószereik segítségével azonosítottuk, illetve gátoltuk. Az alkalmazott gátlószerek:

1. Nisoldipin, $1 \mu \mathrm{M}-\mathrm{I}_{\mathrm{ca}}$-áram-blokkoló.

2. Dofetilid, 0,1 $\mu \mathrm{M}-\mathrm{I}_{\mathrm{Kr}}$-áram-blokkoló.

3. HMR 1556, 0,5 $\mu \mathrm{M}$ - $\mathrm{I}_{\mathrm{Ks}}$-áram-blokkoló.

4. Tertiapin, $10 \mathrm{nM}-\mathrm{I}_{\mathrm{K}, \mathrm{ACh}}$-áram-blokkoló.

5. 4-aminopyridin (4-AP) - I to-áram-blokkoló.

\section{Statisztika}

Az adatok (átlag $\pm S E M)$ statisztikai elemzése egymintás Student t-próbával történt. A p-értéket akkor tekintettük szignifikánsnak, ha értéke kisebb volt, mint 0,05.

\section{Eredmények}

Tranziens kifelé haladó káliumáram ( $\left.\left.\right|_{\text {to }}\right)$

A tranziens kifelé haladó káliumáramot két kísérletes protokoll segítségével is megvizsgáltuk. Először egy, az áram kinetikai paramétereit jobban modellező, ún. akciós potenciálszerű protokollal mértük. $A z I_{\text {to }}$-áramot magas koncentrációjú 4-aminopyridin (3 mM 4-AP) gátlószerével azonosítottuk. Így az áramot a kontrollkörülmények (3. $A$ ábra, bal felső mező) és a gátlószer után (3. $A$ ábra bal alsó mező) regisztrált áramgörbék különbségeként (3. A ábra jobb oldali mező) határoztuk meg.

$A z I_{\text {to }}-t$ a szokásos négyszögpulzusokkal aktivált áramként is megvizsgáltuk. Ennek során az $\mathrm{I}_{\text {to }}$-áramot 0,33 Hz pulzusfrekvencia mellett négyszögjel formájú 300 ms időtartamú depolarizáló feszültségimpulzusokkal aktiváltuk, és a -20 mV-tól 50 mV-ig terjedő potenciáltartományt vizsgáltuk.

A holding potenciál (HP) $-90 \mathrm{mV}$ volt (3. B ábra és 4.A ábra, felső panel). A kontrollmérések során egy gyorsan aktiválódó és igen nagy amplitúdójú $\mathrm{I}_{\text {to }}$-áramot (mintegy 14-15 pA/pF) regisztráltunk. Ezután 3 mM 4-aminopyridint adtunk az oldathoz. Azt tapasztaltuk, hogy a 3 mM 4-AP, az eddig publikált adatoknak megfelelően, teljes mértékben gátolta az $\mathrm{I}_{\mathrm{to}}$-áramot (3. $B$ ábra). A kontroll és az anyag hatása utáni mérés különbségéből megkaptuk a 4-aminopiridin-érzékeny áramot. Ezután megvizsgáltuk az $\mathrm{I}_{\text {to }}$-áramot pitvarfibrilláló (PF) kutyákból izolált pitvarsejtekben is (4. A ábra). Megál- 
lapítottuk, hogy az $\mathrm{I}_{\text {to }}$-áram nagysága, ha kismértékben is, de csökkent („downregulálódott”). Ez a különbség nem bizonyult statisztikailag szignifikánsnak (4. $A$ és 4 . $B$ ábrák).

Megvizsgáltuk az $\mathrm{I}_{\text {to }}$-áram inaktivációját „SR- és „PFsejteken” egyaránt. A pitvarsejtekben az $\mathrm{I}_{\text {to }}$-áram kinetikája legjobban kétkomponensű (egy gyors és egy lassabb időállandójú), exponenciális függvénnyel volt a legtökéletesebben illeszthető (5. ábra).

Kutya kamrai szívizomsejtjeiben jelen van egy rendkívül gyors (mintegy 10-12 ms időállandójú) $I_{\text {to }}$-komponens, viszont a pitvarsejtekben mért lassú(bb) kinetikájú időállandó (mintegy 120-150 ms) jelentősen lassúbb volt, mint amit korábban kutyából izolált kamrai myocytákon mértünk (+20 mV-on mérve mintegy mintegy 20-30 ms) (18) ). A „PF-sejtekben” is két exponenciális kinetikájú volt az $\mathrm{I}_{\text {to }}$-áram inaktivációja viszont mind a gyors, mint a lassú kinetikájú komponens konstans szignifikáns mértékben lassult (5. ábra és 1. táblázat). Az illesztések eredményeit (amplitúdók és inaktivációs állandók) az 1. táblázat foglalja össze.

\section{A befelé egyenirányító káliumáram $\left(I_{\mathrm{K} 1}\right)$}

A befelé egyenirányító káliumáramot a rutinszerű mikroelektrofiziológiai vizsgálatokban megszokott módon vizsgáltuk. Az $\mathrm{I}_{\mathrm{K} 1}$-áramot $-90 \mathrm{mV}$ holding potenciálról 0,33 Hz pulzusfrekvencia mellett 300 ms időtartamú depolarizáló négyszögimpulzusokkal aktiváltuk, és a pulzus végén nem inaktiválódó áramként $\left(I_{s s}\right.$, ún. „ste- ady-state" áram) határoztuk meg (6. A ábra, szaggatott vonalakkal jelzett terület).

A 6. A ábrán is (bal oldali eredeti regisztrátum-felvételek), de a kísérleteket összesítő áramfeszültség karakterisztikákon (6. $B$ ábra, felső panel) is jól látható, hogy a pitvari $\mathrm{I}_{\mathrm{K} 1}$-áram „PF-kutyamodellünkben” erősödik („upregulálódik”), de a növekedés a pitvari akciós potenciált meghatározó feszültségtartományban (-80 mV és $20 \mathrm{mV}$ között) nem különbözik statisztikailag szignifikánsan az „SR- és PF-„, cardiomyocytákban (6. ábra jobb alsó panel).

\section{$A z$ acetilkolin-függő káliumáram $\left(I_{k}, A C h\right)$}

Az $I_{K, A C h}$ káliumáram fiziológiás körülmények között csak a bolygóideg stimulációja alatt aktív. Ezért az áramot a kolinerg agonista carbachol $(2 \mu \mathrm{M})$ segítségével aktiváltuk. Az áramot egy fürészfog (ramp) feszültségprotokoll segítségével tanulmányoztuk. SR-sejtekben kolinerg aktiváció nélkül mind befelé (inward), mind kifelé haladó (outward) irányban viszonylag alacsony amplitúdójú áramot mértünk (7. ábra). Amennyiben a tápoldathoz hozzáadtunk $2 \mu \mathrm{M}$ carbacholt, az áram nagysága mind inward, mint az outward irányban jelentősen megnőtt (7. ábra).

$A z$ így aktiválódott áramot a szelektív $I_{K, A C h}$-gátlónak tartott tertiapin $(10 \mathrm{nM})$ jelentős mértékben gátolta (7. ábra). „PF-sejtekben” minden előzetes aktiváció nélkül jelentős, konstitutívan aktív $\mathrm{I}_{\mathrm{K}, \mathrm{ACh}}$-áramot mértünk, amelyet a tertiapin $26 \%$-ban gátolt (7. ábra, középső mezők).

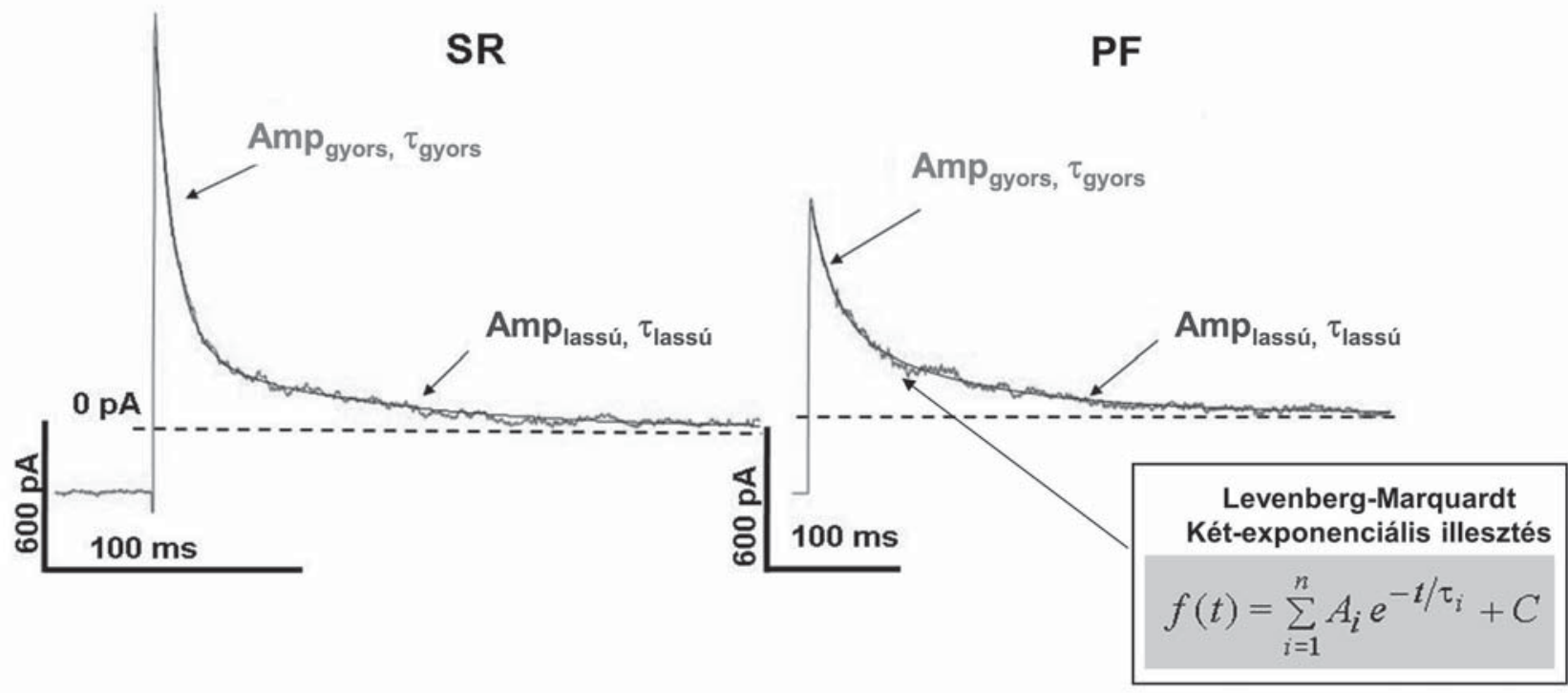

5. ÁBRA. Ito-áram inaktivációs kinetikája izolált SR és PF kutya pitvari szívizomsejteken kettős exponenciális Levenberg-Marquardt-féle egyenlettel illesztve

1. TÁBLÁZAT. Az lo-áram gyors és lassú komponensének inaktivációs állandói ( $\tau$ ) és a hozzátartozó amplitúdók (Amp) 20 mV-os feszültségnél mérve izolált „SR- és PF-kutya” pitvari szívizomsejtjein

\begin{tabular}{|c|c|c|c|c|}
\hline Paraméter & $\tau_{\text {gyors }}$ (ms) & $\tau_{\text {lassú }}(\mathbf{m s})$ & $\operatorname{Amp}_{\text {gyors }}(\mathbf{p} / \mathbf{p F})$ & $A_{m p} p_{\text {lassú }}(p / p F)$ \\
\hline $\operatorname{SR}(n=10)$ & $11,70 \pm 0,76$ & $121,9 \pm 8,82$ & $5,80 \pm 0,61$ & $2,32 \pm 0,38$ \\
\hline$P F(n=11)$ & $17,83 \pm 2,97$ & $179,2 \pm 25,42$ & $4,22 \pm .0,7$ & $2,71 \pm 0,35$ \\
\hline
\end{tabular}



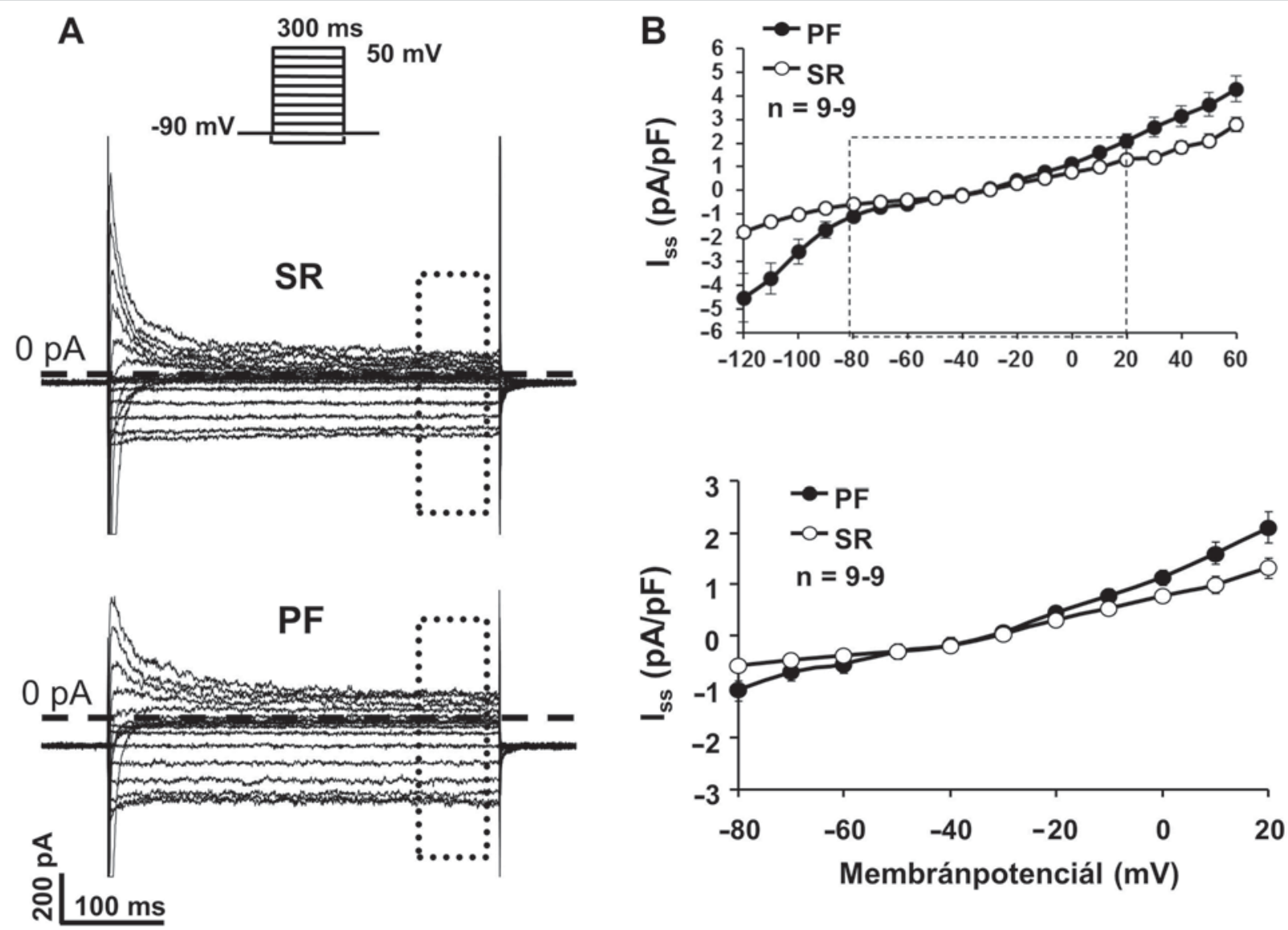

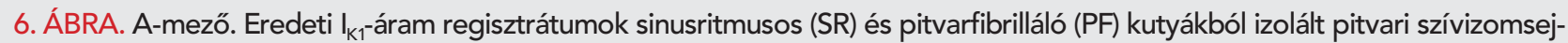
teken. B-mező. I $\mathrm{K}_{1}$-áram-feszültség (I-V) karakterisztika „SR- és PF- „ kutya pitvari sejteken (n=9-9; p=ns)

Ezzel igazoltuk kutyából izolált szívizomsejteken is azt a korábbi megfigyelést, hogy humán permanens PFben szenvedő betegekben jelen van egy ligand független konstitutív $I_{K, A C h}$-áram is, amely feltehetöleg jelentős mértékben hozzájárul a humán pitvari elektrofiziológiai remodellinghez (12). Ha a „PF-sejteket” carbachollal kezeltük, a konstitutív $I_{K, A C h}$-ionáramon kívül egy másik, szintén tertiapin-szenzitív, de ligandfüggő $I_{K, A C h}$-ionáram jelent meg (7. ábra, jobb oldali mezők).

\section{Megbeszélés}

Tranziens kifelé haladó káliumáram $\left(I_{\text {to }}\right)$ Kísérletes eredményeink egyértelműen igazolják egy jelentős (mintegy 14-15 pA/pF) amplitudójú tranziens kifelé haladó káliumáram jelenlétét kutya pitvari szívizomsejtjeiben. Ennek az áramnak a jelenléte okozza a pitvarsejtek akciós potenciáljára nagyon jellemző spike and dome-konfigurációt is (2. ábra; SR pitvari sejt akciós potenciál). A kísérletesen előidézett PF-töl sújtott kutyák szívéből izolált myocytákban hasonló méretü $\mathrm{I}_{\mathrm{to}}$-áramot mértünk. Ez a megfigyelés jelentősen eltér a PF-ben szenvedő páciensek pitvari szívizomsejt-mintáiban mért eredményektöl: emberben az $I_{\text {to }}$ natív áramnak mind a sürüsége, mind az áramot alkotó fehérje és a kódoló mRNS-szintjei jelentősen mérséklődnek („downregulálódnak”). Ezen különbség (ember vs. kutya) okát nem tudjuk. Egy korábbi, a miénkhez hasonló kutyamodellben, 6 hétig folyamatosan fenntartott gyors szívingerléssel kiváltott PF-es állatrokból izolált szívizomsejteken kimutatták az $\mathrm{I}_{\mathrm{to}}$-áramot meghatározó Kv4.3 mRNS-szintek „downregulációját” (19). Az említett vizsgálatban nem mértek közvetlenül natív $\mathrm{I}_{\mathrm{to}}$-áramot, és mint tudjuk, az $\mathrm{I}_{\mathrm{to}}$-áram több pórusformáló $\alpha$-alegység (Kv4.2, Kv4.3 és Kv1.4) és kiegészítő ß-alegység (KChIP2, miRP1 stb.) koexpressziójából áll össze (20). Természetesen az a lehetőség sem kizárt, hogy az általunk alkalmazott 4-6 hétig fönntartott gyors szívingerlés $(400 / \mathrm{min})$ nem elégséges az $\mathrm{I}_{\text {to }}$-áram humán krónikus vagy permanens PF-ben észlelhető "downregulációjának" reprodukciójához, vagy az eltérés oka egyszerüen species különbség.

Az $\mathrm{I}_{\mathrm{to}}$-áram inaktivációs kinetikáját kétexponenciális függvénnyel illesztettük. Méréseink eredménye alapján az $\mathrm{I}_{\mathrm{to}}$-áram kinetikája egy gyors $(\tau \sim 12 \mathrm{~ms})$ és egy lassúbb ( $\tau \sim 122-150 \mathrm{~ms})$ komponensből tevődik össze. Ez jelentősen eltér a kamrai szívizomsejtekben kimutatott áramkinetikai értékektöl, ahol a gyors kinetika állandója hasonló a pitvaréhoz ( $\tau \sim 4-5 \mathrm{~ms})$, de a lassú összetevő jelentősen gyorsabb ( $\tau \sim 20-25 \mathrm{~ms})$, mint a pitvari érték 

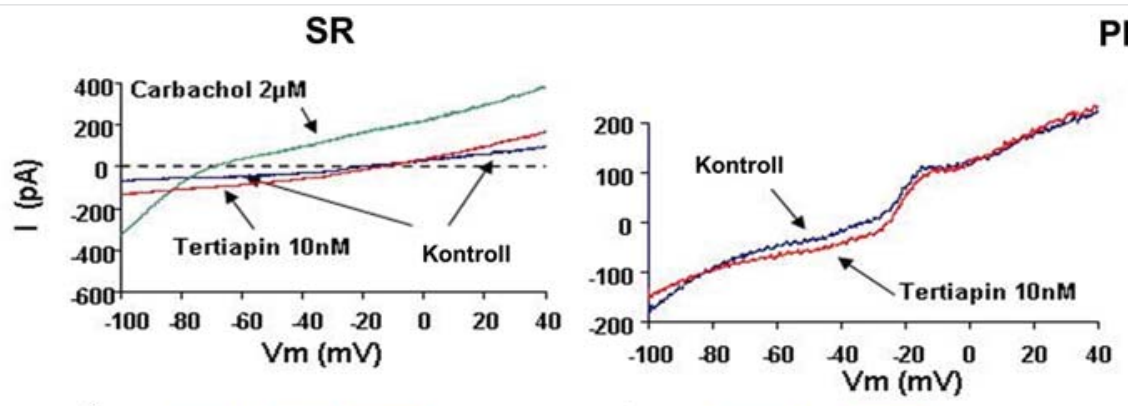

PF
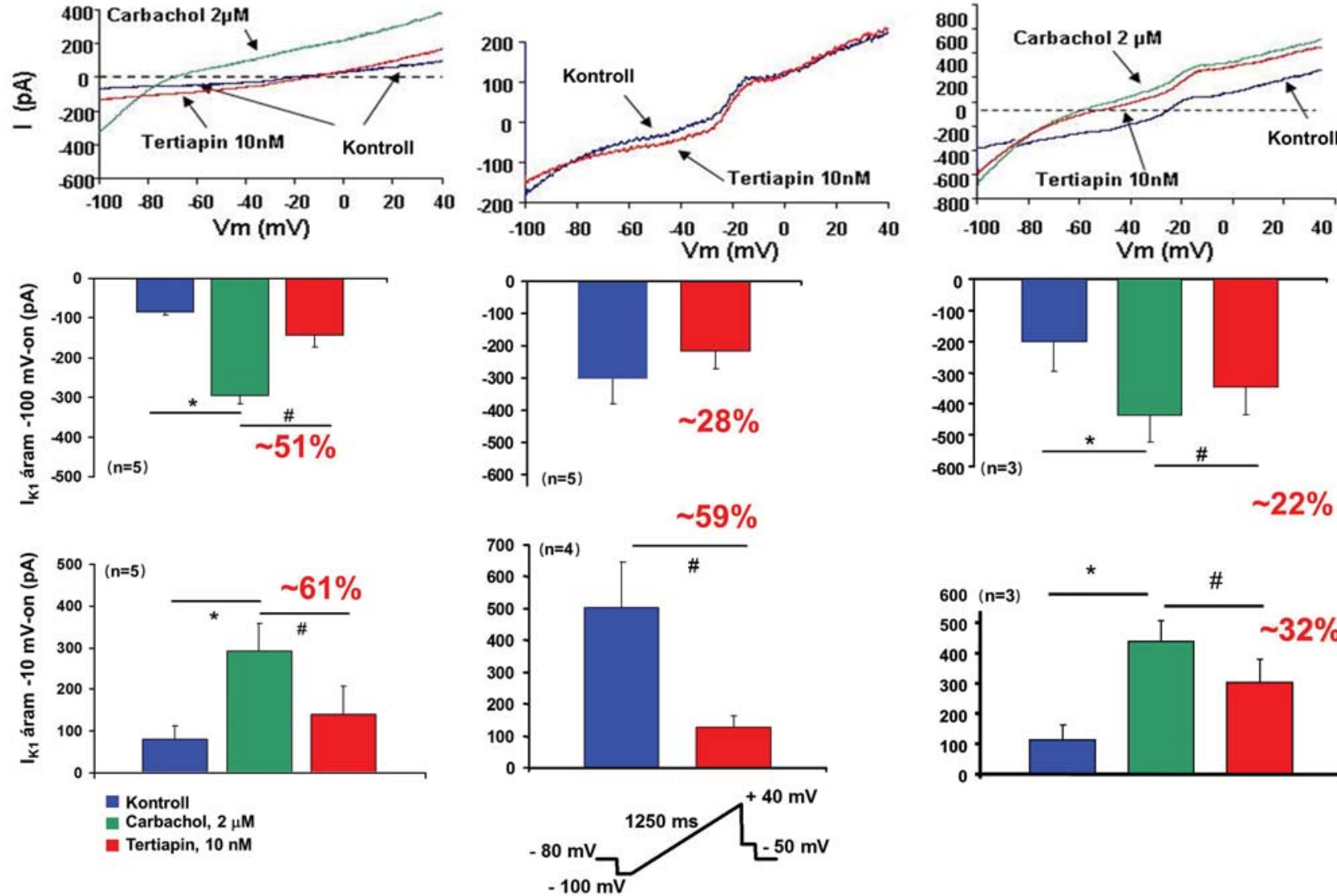

$\sim 22 \%$

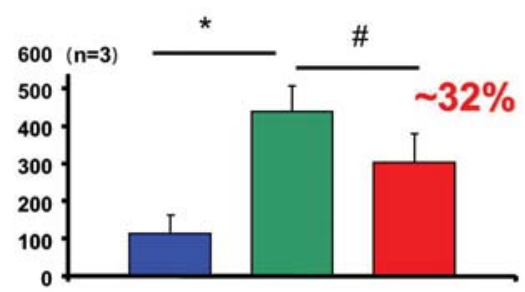

7. ÁBRA. Az $I_{K, A C h}$-áram SR-ben lévő és pitvarfibrilláló (PF) kutyából izolált pitvarsejtekben. - 100 mV-ról 40 mV-ra depolarizáló fürészfogszerü (ramp) protokollt alkalmaztunk. Az $\mathrm{I}_{K, A C h}$-áramot a kolinerg agonista carbachollal $(2 \mu \mathrm{M})$ aktiváltuk és tertiapinnal (10 nM) blokkoltuk. Az oszlopdiagramok a -100 mV-on (inward tartomány, középső sor), illetve -10 mV-on (outward tartomány, alsó sor) mért $I_{K, A C h}$-áramok amplitúdóját demonstrálják. Alul szemléltettük az alkalmazott fürészfogszerű (ramp) protokollt.

(18). Ebből a megfigyelésből arra a fontos következtetésre juthatunk, hogy pitvaron az $\mathrm{I}_{\text {to }}$-áram nemcsak a korai 1. fázis repolarizációt determinálja, hanem a mintegy 100-150 ms hosszú lassú komponens(e) révén szerepet játszhat a pitvarsejtek későbbi repolarizációjában. A pitvarfibrilláló kutyák $\mathrm{I}_{\text {to }}$-ja szintén két exponenciális függvénnyel illeszthető. Mindkét komponens időállandója valamelyest lassúbb lett, ami részlegesen hozzájárulhat a pitvari akciós potenciál remodellinghez.

\section{Befelé egyenirányító káliumáram $\left(\mathrm{I}_{\mathrm{K} 1}\right)$ vizsgálata}

A befelé egyenirányító káliumáram legfontosabb szerepe a késői repolarizáció utáni fázisban a membránpotenciál helyreállítása (21), de újabb tanulmányok kimutatták, hogy közvetlen szerepe lehet az akciós potenciál 3. fázisának alakításában, azaz a késői repolarizációban is (22). Eredményeink alapján az $\mathrm{I}_{\mathrm{K} 1}$-áram egyaránt jelen van az SR-ben és kísérletesen indukált „PF-es kutyák pitvari myocytáiban. Utóbbiban (ti. PFben) az I $\mathrm{K}_{\mathrm{K} 1}$-áram enyhén erősödik („upregulálódik”), ami hasonló a humán krónikus „PF-sejtekben” mért adatokkal (11), amelyek arról tanúskodnak, hogy az $\mathrm{I}_{\mathrm{K} 1}$-áram denzitása, és az áram karakterisztikumai meghatározó fehérje és mRNS-szintek egyaránt erősödnek („upregulálódnak”). Érdemes megjegyezni, hogy kísérleteinkben $a z I_{K 1}$-áram sürüségének növekedése a pitvari akciós potenciált meghatározó feszültségtartományban (-80 mV és 20 mV között) nem különbözik statisztikailag szignifikáns módon az „SR-es és PF-es” kutyákból izolált pitvari myocytákban (-80 mV és $20 \mathrm{mV}$ között) (6. ábra alsó panel).

\section{Az acetilkolin-függő káliumáram ( $\left.I_{K, A C h}\right)$}

Pitvari szívizomsejtekben létezik egy speciális háttér egyenirányító káliumáram, amely nem expresszálódik a kamrasejtekben. Ez az acetilkolin szenzitív káliumáram, az $I_{K, A C h}$ (23). A n. vagus (paraszimpatikus)-izgalom kapcsán felszabaduló acetilkolin (ACh) stimulálja a muszkarin-receptorokat és azok aktiválják az $\mathrm{I}_{\mathrm{K}, \mathrm{ACh}}$-áramot (24). Eddigi ismereteink szerint az $\mathrm{I}_{\mathrm{KA}, \mathrm{Ch}}$-áram a ligand stimulációja nélkül inaktív. Köztudott, hogy az extrinszik és intrinszik vegetatív (autonóm, szimpatikus/paraszimpatikus) idegrendszer döntő mértékben hozzájárul a PF kialakulásához és/vagy fennmaradásához. Tudjuk, hogy a bolygóideg-izgalom hatására a 
pitvari APD és ERP rövdül, és az ACh egyenlőtlen felszabadulása miatt (is) növekszik a pitvari repolarizáció diszperziója/inhomogenitása (25). A paraszimpatikus izgalom arrhythmogen „táptalaja” a re-entry-rotorok keletkezésének és a PF fellépésének $(1,26)$, amely gyakran előfordul a klinikai gyakorlatban az ún. vagotóniás/ Coumel-típusú PF-ben $(27,28)$. Természetesen felvetődő kérdés, hogy a vagus-izgalomtól (alvás, posztprandiális állapot stb.) indukált PF kialakulásában az $\mathrm{I}_{\mathrm{K}, \mathrm{ACh}}$-áram intenzitásának változása, „remodellingje” is szerepet játszik. Dobrev és munkatársai 2001-ben kimutatták, hogy az $\mathrm{I}_{\mathrm{K} 1}$-áram „upregulációjával” párhuzamosan az $I_{K, A C h}$-áramot meghatározó GIRK4-fehérje expressziója csökken, ezért az $\mathrm{I}_{\mathrm{K} 1}$ „upregulációjával” és $\mathrm{I}_{\mathrm{CaL}}$ erősségének csökkenésével magyarázták az ATR-t (11). Később ugyanez a munkacsoport kimutatta, hogy ATR során nem csupán az $\mathrm{I}_{\mathrm{CaL}}$-áram expressziója csökken, hanem, egyelőre részleteiben még nem teljesen tisztázott foszforilációs-szignalizációs mechanizmus kapcsán (29) permanens PF-ben az $\mathrm{I}_{\mathrm{K}, \mathrm{Ach}}$-csatornák, előzetes ligand-stimuláció nélkül, „konstitutívan” nyitva maradnak $(12,30)$. Ez egy meglepő eredmény volt, mert ez volt az első olyan vizsgálat, amely igazolta, hogy az $I_{K, A C h}$-csatornák előzetes ligand-stimuláció nélkül is képesek aktív áram-átvitelre speciális aritmiaformá(k)ban (pl. permanens PF-ben). Ez a konstitutívan aktív $I_{K, A C h}$-áram tehát hozzájárul az PF-re jellemző rövid és háromszögesített („trianguláris”) APD-morfológiához (lásd 2. ábra) (PF pitvari szívizomsejt akciós potenciál), és vélhetően szerepet játszik a pitvari re-entry típusú aritmogenezisben (12). A pitvarspecifikus (csak a pitvarizomzatban jelenlévő) $I_{K A C h}$-gátlás (pl. tertiapinnal) nem okoz kamrai repolarizáció megnyúlást, így valószínű, hogy nem várható olyan proaritmiás mellékhatás (Torsades de Pointes kamrai tachycardia), amilyet a jelenleg (egyre ritkábban) használt „klasszikus” I $\mathrm{Kr}_{\mathrm{r}}$-gátlók (pl. dofetilid) okoznak (31). Ennek megfelelően többször felvetődött a hipotézis, hogy ezen konstitutívan aktív $I_{K, A C h}$-áramnak a szelektív inhibltorai ideális pitvarspecifikus antiaritmiás hatású gyógyszerek lehetnének, amelyek alkalmasak a paraszimpatikus izgalomtól iniciált PF gyógyszeres terápiájára $(12,30)$. A hipotézist igazolandó számos gyógyszerjelöltet próbáltak ki különféle állatkísérletes modellekben, és az előzetes eredmények bíztatóak $(32,33)$.

Jelen kísérleteinkben igazoltuk a konstitutív $\mathrm{I}_{\mathrm{K}, \mathrm{ACh}}$-áram jelenlétét (amint ez a 7. ábra középső mezőiben látható). A „PF-cardiomyocytákban” a kolinerg agonista carbachol jelenléte nélkül is identifikálható egy tertiapin-szenzitív áramkomponens (piros görbe és oszlopok), mind az inward (-100 mV-on), mind az outward tartományban (-10 mV-on). Ez bizonyítja, hogy az $\mathrm{I}_{\mathrm{K}, \mathrm{ACh}}$-áram ligandfüggetlen (acetilkolin híján is müködő) típusa is „konstitutívan” jelen vant a „PF-es” kutyákból izolált pitvarizomsejtekben. Hozzá kell tenni, hogy ez az áram nagyon alacsony denzitású, különösen outward irányban, ezért megkérdőjelezhető, hogy a kons-

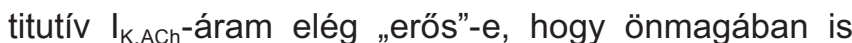
kiváltsa a PF-re jellemző elektromos remodellinget (a markáns pitvari ERP- és APD-rövidülést).

Jelen kísérleteink alapján megengedhetőnek látszik egy új hipotézis körvonalazása. A paraszimpatikus (alap)tónus magától értődően normális körülmények között is mindig jelen van. A vagus-rostoktól/ACh-tól stimulált $I_{K, A C h}$-áram tehát folyamatosan és mindig jelen van a pitvari szívizomsejtekben, amelyhez hozzáadódhat a konstitutívan aktivált $\mathrm{I}_{\mathrm{K}, \mathrm{ACh}}$-áram. Utóbbi „atípusos" ionáramnak szerepe lehet a PF állandósulásában a permanens típus kialakulásában. A 7. ábra jobb oldali mezőiben bemutatott kísérletek valóban azt igazolják, hogy amennyiben a pitvari remodellingel rendelkező kutyákból izolált myocytákat előzetesen carbachollal aktiváltuk, az így létrehozott áram (amely a konstitutív és carbachollal indukált a $I_{K, A C h}$-áramot egyaránt tartalmazza, különösen outward irányban már elegendően nagy (7. ábra, jobb alsó panel), hogy a tertiapin blokkolása is szignifikánsan nagyobb áramkomponens jelenlétét igazolja. Ez az áram, már kellően erős lehet, hogy hozzájáruljon az PF-re jellemző trianguláris és rövid APD-hez.

E hipotézist igazolandó, a közelmúltban Juhász és munkatársai kimutatták, hogy a tertiapin képes volt kivédeni a gyors pitvari szívingerléssel kiváltott pitvari elektromos remodelling talaján kialakuló kísérletes PFet kutyákban (34). További humán vizsgálatok szükségesek annak igazolására, hogy az $\mathrm{I}_{\mathrm{K}, \mathrm{ACh}}$ gátlása klinikai körülmények között is hasznosítható lesz-e a PF megelőzésében, megszüntetésében és/vagy állandósulásának profilaxisában.

\section{Következtetések}

A pitvari $I_{\text {to }}$-áram a lassú inaktivációs kinetika miatt a pitvari szívizomsejtekben jelentősebb mértékben hozzájárulhat a késői repolarizációhoz, mint amilyet a kamrai szívizomsejtekben kimutattak. Az I to-áram kutyamodellünkben a humán adatokkal ellentétben, csak kis mértékben „downregulálódott” PF-ben, viszont inaktivációs kinetikája szignifikánsan lassult.

A konstitutív $I_{K, A C h}$ megjelenése bizonyítja, hogy PF-kutyamodellünkben a pitvari elektromos remodelling kialakult. A ligandfüggő és konstitutívan aktív $\mathrm{I}_{\mathrm{K}, \mathrm{ACh}}$-áramok együttesen feltehetően fontos szerepet játszanak (legalábbis kutyában) az PF-re jellemző háromszög alakú, a fiziológiásnál is rövidebb akcióspotenciál-jelforma kialakításában.

\section{Köszönetnyilvánítás}

A jelen munka a Nemzeti Kutatási, Fejlesztési és Innovációs Hivatal (OTKA NN-109904, NN-110896, K-119992 és GINOP-2.3.2-15-2016-00006), a TÁMOP 4.2.4.A/2-11-1-2012-0001 azonosító számú Nemzeti Kiválóság Program (Hazai hallgatói, illetve kutatói 


\section{személyi támogatást biztosító rendszer kidolgozása és müködtetése országos program) és a Magyar Tudomá- nyos Akadémia támogatásával készült. \\ Megkülönböztetett köszönetünket szeretnénk kifejezni Prof. dr. Papp Gyula akadémikusnak, aki a jelen dolgo- zat szinte valamennyi szerzőjének a pályáját és szakmai tevékenységét mindvégig messzemenően támogatta.}

Irodalom

1. Nattel S. New ideas about atrial fibrillation 50 years on. Nature 2002; 415: 219-26. https://doi.org/10.1038/415219a

2. Wijffels MCEF, Kirchhof CJHJ, Dorland R, et al. Atrial fibrillation begets atrial fibrillation. A study in awake, chronically instrumented conscious goats. Circulation 1995; 92: 1954-1968. https://doi.org/ 10.1161/01.CIR.92.7.1954

3. Nattel S. Atrial electrophysiological remodeling caused by rapid atrial activation: underlying mechanisms and clinical relevance to atrial fibrillation. Cardiovasc Res 1999; 42: 298-308. https://doi.org/ 10.1016/S0008-6363(99)00022-X

4. Jost N, Fazekas T. Pitvari (elektromos, kontraktilis és strukturális) remodelling. In. Pitvarfibrilláció. A szívizomsejttől a betegágyig (szerk. Fazekas T, Bogáts G, Csanádi Z, Jost N, Lőrincz I). Medicina Kiadó; 2010. pp. 91-138.

5. Lu Z, Scherlag BJ, Lin J, et al. Atrial fibrillation begets atrial fibrillation: autonomic mechanism for atrial electrical remodeling induced by short-term rapid atrial pacing.Circ Arrhythm Electrophysiol 2008; 1(3):184-192. https://doi.org/10.1161/CIRCEP.108.784272

6. Sheng X, Scherlag BJ, Yu L, et al. Prevention and reversal of atrial fibrillation inducibility and autonomic remodeling by low-level vagosympathetic nerve stimulation. J Am Coll Cardiol 2011; 57: 563-571. https://doi.org/10.1016/j.jacc. 2010.09.034

7. Chen YJ, Chen SA, Chen YC, et al. Effects of rapid atrial pacing on the arrhythmogenic activity of single cardiomyocytes from pulmonary veins: implication in initiation of atrial fibrillation. Circulation 2001; 104: 2849-2854. https://doi.org/10.1161/hc4801.099736

8. Burstein B, Qi XY, Yeh YH, et al. Atrial cardiomyocyte tachycardia alters cardiac fibroblast function: a novel consideration in atria remodeling. Cardiovasc Res 2007; 76: 442- 452. https://doi.org/10.1016/j.cardiores.2007.07.013

9. Yue L, Feng J, Gaspo R, et al. Ionic remodeling underlying action potential changes in a canine model of atrial fibrillation. Circ Res 1997; 81: 512-525. https://doi.org/10.1161/01.RES.81.4.512

10. Christ T, Boknik P, Wöhrl S, et al. Reduced L-type $\mathrm{Ca}^{2+}$ current density in chronic human atrial fibrillation is associated with increased activity of protein phosphatases. Circulation 2004; 110: 2651-2657. https://doi.org/10.1161/01.CIR.0000145659.80212.6A

11. Dobrev D, Graf E, Wettwer E, et al. Molecular basis of downreg ulation of G-protein-coupled inward rectifying $\mathrm{K}^{+}$current $\left(\mathrm{I}_{\mathrm{K}, \mathrm{ACh}}\right)$ in chronic human atrial fibrillation: decrease in GIRK4 mRNA correlates with reduced $I_{K A C h}$ and muscarinic receptor-mediated shortening of action potentials. Circulation 2001; 104: 2551-2557. https:// doi.org/10.1161/hc4601.099466

12. Dobrev D, Friedrich A, Voigt N, et al. The G-protein gated potassium current $I_{K, A C h}$ is constitutively active in patients with chronic atrial fibrillation. Circulation 2005; 112: 3697-3706. https://doi.org/ https://doi.org/10.1161/CIRCULATIONAHA.105.575332

13. Sun H, Gaspo R, Leblanc N, Nattel S. Cellular mechanisms of atrial contractile dysfunction caused by sustained atrial tachycardia. Circulation 1998; 98: 719 -727. https://doi.org/10.1161/01. CIR.98.7.719

14. Schotten U, Duytschaever M, Ausma J, Eijsbouts S, Neuberger $\mathrm{HR}$, Allessie M. Electrical and contractile remodeling during the first days of atrial fibrillation go hand in hand. Circulation 2003; 107: 1433-1439. https://doi.org/10.1161/01.CIR.0000055314.10801.4F 15. Courtemanche M, Ramirez RJ, Nattel S. Ionic targets for drug therapy and atrial fibrillation-induced electrical remodeling: insights from a mathematical model. Cardiovasc Res 1999; 42: 477-489. htt-
ps://doi.org/10.1016/S0008-6363(99)00034-6

16. Tieleman RG, Van Gelder IC, Bosker HA, et al. Does flecainide regain its antiarrhythmic activity after electrical cardioversion of persistent atrial fibrillation? Heart Rhythm 2005; 2: 223-230. 10.1016/j.hrthm.2004.11.014

17. Duytschaever M, Blaauw Y, Allessie M. Consequences of atrial electrical remodeling for the anti-arrhythmic action of class IC and class III drugs. Cardiovasc Res 2005; 67: 69-76. https://doi.org/ 10.1016/j.cardiores.2005.02.019

18. Virág L, Jost N, Papp R, et al. Analysis of the contribution of $I_{\text {to }}$ to repolarization in canine ventricular myocardium. $\mathrm{Br} \mathrm{J}$ Pharmacol 2011; 164: 93-105. https://doi.org/10.1111/j.1476-5381.2011.01331.x 19. Yue L, Melnyk P, Gaspo R, et al. Molecular mechanisms underlying ionic remodeling in a dog model of atrial fibrillation. Circ Res 1999; 84: 776-784. https://doi.org/10.1161/01.RES.84.7.776

20. Jost $\mathrm{N}$. Transmembrane ionic currents underlying cardiac action potential in mammalian hearts. In. Advances in cardiomyocyte research. Ed. Péter P. Nánási. Transworld Research Network, Tivandrum, Kerala, India; 2009. p. 1-45.

21. Anumonwo JMB, Lopatin AN. Cardiac strong inward rectifier potassium channels. J Mol Cell Cardiol 2010; 48: 45-54. https://doi. org/10.1016/j.yjmcc.2009.08.013

22. Biliczki $P$, Virág $L$, lost $N$, et al. Interaction of different potassium channels in cardiac repolarization in dog ventricular preparations: role of the repolarization reserve. Br J Pharmacol 2002; 137: 361368. https://doi.org/10.1038/sj.bjp.0704881

23. Heidbüchel $H$, Vereecke J, Carmeliet E. Three different potassium channels in human atrium: contribution to the basal potassium conductance. Circ Res 1990; 66: 1277-1286. https://doi. org/10.1161/01.RES.66.5.1277

24. Yamada M, Inanobe A, Kurachi Y. G protein regulation of potassium ion channels. Pharmacol Rev 1998; 50: 723-757.

25. Liu L, Nattel S. Differing sympathetic and vagal effects on atrial fibrillation in dogs: role of refractoriness heterogeneity. Am J Physiol 1997; 273: H805-H816.

26. Kneller J, Zou R, Vigmond EJ, et al. Cholinergic atrial fibrillation in a computer model of a two-dimensional sheet of canine atrial cells with realistic ionic properties. Circ Res 2002; 90: E73-E87. https:// doi.org/10.1161/01.RES.0000019783.88094.BA

27. Yeh YH, Lemola K, Nattel S. Vagal atrial fibrillation. Acta Cardiol Sin 2007; 23: 1-12.

28. Coumel P, Attuel $P$, Lavallée J, et al. Syndrome d'arythmie auriculaire d'origine vagale. Arch Mal Coeur 1978; 6: 643-656.

29. Voigt $N$, Friedrich $A$, Bock $M$, et al. Differential phosphorylation-dependent regulation of constitutively active and muscarinic receptor-activated $I_{\text {K.ACh }}$ channels in patients with chronic atrial fibrillation. Cardiovasc Res 2007; 74: 426-437. https://doi.org/10.1016/j. cardiores.2007.02.009

30. Voigt $\mathrm{N}$, Maguay A, Yeh $x \mathrm{YH}$, et al. Changes in $I_{K, A C h}$ sing le channel activity with atrial tachycardia remodeling in canine at rial cardiomyocytes. Cardiovasc Res 2008; 77: 35-43. https://doi. org/10.1093/cvr/cvm051

31. Lengyel C, Varró A, Tábori K, Papp JG, Baczkó I. Combined pharmacological block of $I_{\mathrm{Kr}}$ and $\mathrm{I}_{\mathrm{Ks}}$ increases short-term QT interval variability and provokes torsades de pointes. $\mathrm{Br} \mathrm{J}$ Pharmacol 2007; 151: 941-951. https://doi.org/10.1038/sj.bjp.0707299

32. Hashimoto N, Yamashita T, Tsuruzoe N. Tertiapin, a selective $I_{\text {KACh }}$ blocker, terminates atrial fibrillation with selective atrial effective refractory period prolongation. Pharmacol Res 2006; 54: 136-41. https://doi.org/10.1016/j.phrs.2006.03.021

33. Hashimoto N, Yamashita T, Tsuruzoe N. Characterization of in vivo and in vitro electrophysiological and antiarrhythmic effects of a novel $I_{\text {KACh }}$ blocker, NIP-151: a comparison with an $I_{\text {Kr }}$-blocker dofetilide. J Cardiovasc Pharmacol 2008; 51: 162-169. https://doi. org/10.1097/FJC.0b013e31815e854c

34. Juhász V, Hornyik T, Benák A, et al, Comparison of the effects of $I_{K A C h} I_{K r}$ and $I_{N a}$ block in conscious dogs with atrial fibrillation and on action potentials in remodeled atrial trabeculae. Can J Physiol Pharmacol epub, 2017; https://doi.org/10.1139/cjpp-2017-0342. 